\title{
PENGARUH SUHU AIR YANG DITAMBAHKAN TERHADAP KUALITAS DONAT KENTANG
}

\author{
The Effect of Added Water Temperatures to The Quality of Potato Donuts \\ Rizka Prima Yunindya, Erni Sofia Murtini* \\ Jurusan Teknologi Hasil Pertanian - Fakultas Teknologi Pertanian - Universitas Brawijaya \\ Jl. Veteran, Malang 65145 \\ *Penulis Korespondensi, email : erni.murtini@ub.ac.id
}

Disubmit: 2 Maret 2020 Direvisi: 26 Maret 2020 Diterima: 4 Juni 2020

\begin{abstract}
ABSTRAK
Donat umumnya berbahan baku terigu, namun adakalanya ditambahkan kentang kukus lumat yang biasa disebut donat kentang. Suhu air yang digunakan dalam pembuatan donat kentang oleh masyarakat sangat bervariasi, mulai dari air es sampai air hangat. Penelitian ini bertujuan untuk mengetahui pengaruh suhu air terhadap kualitas donat kentang dan mendapatkan suhu air untuk menghasilkan donat kentang dengan volume pengembangan optimum. Penelitian dilakukan menggunakan Rancangan Acak Kelompok (RAK) satu faktor yaitu suhu air $\left(5,13,75,22,5,31,25\right.$ dan $\left.40^{\circ} \mathrm{C}\right)$ diulang 3 kali. Donat kentang dibuat dengan menambahkan kentang lumat sebanyak $40 \%$ (b/b terigu) dalam formula, dicampur hingga terbentuk adonan, diistirahatkan, dibulatkan per 30g, difermentasi, dan digoreng. Kualitas donat berupa volume spesifik, daya serap minyak, jumlah dan luasan pori serta profil tekstur dianalisis. Data diolah menggunakan ANOVA dan bila menujukkan beda nyata $(\alpha=5 \%)$ dilanjutkan uji BNT (Beda Nyata Terkecil) $\mathrm{a}=5 \%$. Suhu air optimum ditentukan dengan menggunakan Response Surface Methodology (RSM) One Factor model kuadratik dengan variabel bebas suhu air (X1) dan variabel respon volume pengembangan (Y1). Hasil penelitian menunjukkan bahwa suhu air berpengaruh nyata terhadap volume spesifik, daya serap minyak dan jumlah pori; namun tidak mempengaruhi tekstur dan luasan pori. Hasil verifikasi RSM menunjukkan bahwa suhu air yang ditambahkan sebesar $24,7^{\circ} \mathrm{C}$ pada pembuatan donat kentang memberikan respon volume pengembangan yang maksimum sebesar $155,94 \%$. Donat tersebut memiliki kadar air $28,35 \%$; abu $0,69 \%$; protein $8,30 \%$; lemak 17,68\%; karbohidrat 44,97\%; total gula 14,67\%; serat kasar 5,57\%; volume spesifik 4,39 $\mathrm{cm} 3 / \mathrm{g}$; densitas kamba $0,23 \mathrm{~g} / \mathrm{cm} 3$; daya serap minyak 10,66\%; hardness $131,45 \mathrm{~N}$; cohesiveness 0,81 ; springiness $4,40 \mathrm{~mm}$.
\end{abstract}

Kata Kunci: Donat; Kentang; Optimasi; Suhu Air

\begin{abstract}
Donut is generally made from wheat flour, however it can be added other materials such as mashed potatoes to create potatoes donut. People use various ingredients formulation to make it, including variations in temperature of added water, from cold to warm water. This research aims to discover how the temperature of the added water affects the donut quality as well as the optimum temperature resulting to the maximum volume of the donut. The experiment uses Randomized Complete Design using one factor, temperature of added water $\left(5 ; 13.75 ; 22.5 ; 31.25\right.$; and $\left.40^{\circ} \mathrm{C}\right)$, with three time replications. Potatoes donut is made by adding $40 \%$ mashed potatoes ( $w / w$ of wheat flour) to the formula, mixed to form dough, rested, rounded per $30 \mathrm{~g}$, proofed and fried. The quality parameters of donut such as specific volume, oil absoption, pores number and texture profile are analyzed. Afterwards, the data acquired will be processed by using ANOVA and LSD (Least Significant Difference) at $a=5 \%$. Optimum temperature will be determined using One Factor RSM (Response Surface Methodology) where X1 interprets independent variable, temperature of added water and $Y 1$ interprets response variable, rising volume. The results indicate that
\end{abstract}


added water temperature significantly affects the donut's specific volume, oil absorption capacity, and total pores. Insignificant effect, however, is experienced by texture profile and pores area. RSM verification result suggests that added water at $24,7^{\circ} \mathrm{C}$ results to $155.94 \%$ of increasing volume which is the optimum response. In addition, the donut has $28.35 \%$ of water content, $0.69 \%$ of ash content, $8.3 \%$ of protein, $17.68 \%$ of fat, $44.97 \%$ of carbohydrate, $14.67 \%$ of total sugar, $5.57 \%$ of crude fiber, specific volume of $4.39 \mathrm{~cm} 3 / \mathrm{g}$, bulk density of $0.23 \mathrm{~g} / \mathrm{cm} 3$, oil absorption capacity of $10.66 \%$, hardness of $131.45 \mathrm{M}$, cohesiveness of 0.81 , springiness of $4.4 \mathrm{~mm}$.

Keywords: Donut, Potato; Optimazion; Water Temperature

\section{PENDAHULUAN}

Donat merupakan produk yang umumnya menggunakan terigu yang dikembangkan baik oleh bahan pengembang atau yeast yang selanjutnya diolah dengan digoreng menggunakan minyak. Donat dikenal dari bentuknya yang bulat, baik yang berlubang di tengah atau tidak berlubang namun diisi dengan selai. Bahan utama donat umumnya adalah terigu protein tinggi, dengan bahan lain telur, yeast, gula, garam, margarin/mentega, susu dan air. Proses pembuatan donat hampir sama dengan roti, yaitu pembuatan adonan dan pengembangan, namun dibedakan pada proses akhir yaitu pemanggangan untuk roti dan penggorengan metode deep frying untuk donat (Shih, et al., 2001).

Penggorengan dilakukan dengan panas berkisar $180^{\circ} \mathrm{C}$ selama 2 menit agar donat matang secara merata. Proses penggorengan menurut lee et al. (2017) dapat mengubah adonan menjadi donat dengan rasa dan tekstur yang menarik. Selama penggorengan, air pada adonan dengan cepat menguap, dan minyak dapat masuk ke dalam matrik/rongga yang ditinggalkan oleh air. Pemanasan dengan adanya minyak dapat mengubah adonan menjadi krispi pada bagian luar (crust), namun empuk pada bagian dalam. Proses pemanasan tinggi juga dapat menimbulkan reaksi yang dapat menghasilkan aroma yang spesifik. Donat yang sangat disukai konsumen memiliki aroma harum khas gandum dan yeast, crust yang renyah, crumb yang empuk dan tidak keras, serta tidak banyak menyerap minyak.

Salah satu varian donat yang terkenal di Indonesia adalah donat kentang. Donat dengan bahan dan proses hampir sama dengan donat reguler, namun sebagian terigu digantikan dengan hancuran kentang kukus. Penggunaan kentang selain dapat menurunkan jumlah penggunaan terigu, memberikan rasa yang berbeda, juga dapat menurunkan staling.
Staling merupakan faktor utama yang mampu mengurangi tingkat penerimaan konsumen yang ditandai dengan crust donat menjadi lebih kaku, mengerasnya crumb, menurunnya sensasi mouthfeel, serta berku-rangnya aroma khas donat yang dihasilkan. Zhu (2016) menyatakan bahwa penambahan karbohidrat seperti polisakarida non-pati, pati dari umbiumbian, oligosakarida, dan hidrokoloid dapat dijadikan sebagai solusi anti-staling. Penambahan kentang juga diharapkan dapat mempertahankan air dalam adonan donat, menurut Nouri et al (2017) semakin banyak jumlah air yang dapat dipertahankan dalam adonan, maka daya serap minyak pada produk akan semakin menurun. Namun demikian, penambahan kentang dapat menurunkan volume pengembangan donat, sehingga dalam pembuatan donat diperlukan emulsifier misalnya kuning telur atau lesitin dari edamame (Murtini dan Putri, 2017).

Tidak seperti donat komersial dari terigu yang banyak diproduksi oleh perusahaan yang telah mapan, donat kentang kebanyakan diproduksi pada skala usaha kecil dan menengah (UMKM). Permasalahan yang terja-di pada pengolahan donat mengandung kentang adalah pengembangan volume yang tidak seragam. Salah satu hal yang dapat menimbulkan permasalahan tersebut diduga adalah suhu air yang ditambahkan saat proses pencampuran adonan. Berbagai resep donat tertulis untuk menambahkan air dingin bahkan air es saat pencampuran adonan, tetapi tak sedikit pula yang menyarankan untuk menggunakan air hangat kuku.

Suhu air yang ditambahkan saat pencampuran adonan dapat berpengaruh terhadap pengembangan volume donat mengandung kentang karena suhu air akan berdampak pada sifat fungsional gluten, aktivitas enzim, dan aktivitas yeast yang berhubungan dengan kualitas akhir produk donat mengandung kentang. Suhu air yang optimum akan 
membuat aktivitas yeast optimum dengan memproduksi karbondioksida hasil aktivitas fermentasi, yang membuat jumlah pori meningkat serta meningkatkan volume (Elmehdi, 2007). Aktivitas enzim yang optimum mampu meningkatkan karakteristik serta kualitas produk berbahan dasar terigu (Rosell and Collar, 2008). Suhu dan jumlah air mempengaruhi konformasi gluten yang berdampak pada karakteristik reologi adonan (Wang et al., 2015).

Penelitian ini bertujuan untuk mempelajari pengaruh suhu air yang ditambahkan terhadap kualitas fisik donat mengandung kentang dan untuk menentukan suhu air yang optimum sehingga dihasilkan donat kentang dengan volume pengembangan yang maksimal. Donut dengan volume pengembangan maksimal dianggap sebagai perlakuan terbaik, dan selanjutnya dianalisa kimia untuk menentukan informasi nilai gizi per takaran saji

\section{METODE}

Bahan-bahan yang digunakan dalam pembuatan donat kentang adalah kentang kuning varietas Cisoma ukuran sedang (6-7 umbi/kg) dengan mata umbi dangkal yang diperoleh dari Pasar Sawojajar, Malang, Jawa Timur. Terigu protein tinggi (Cakra Kembar), margarin (Blue Band), ragi (Fermipan), telur ayam, gula halus (Cap Legi), susu bubuk (Indomilk Full Cream Plain), garam dapur (Cap Kapal), minyak goreng (Tropical), dan air matang. Bahan yang digunakan untuk analisa volume donat adalah juwawut. Bahan kimia untuk analisa kimia donat kentang meliputi : larutan petroleum eter p.a (Sigma-Aldrin), $\mathrm{H}_{2} \mathrm{SO}_{4}$ p.a (Merck), tablet Kjedahl (Merck), asam borat (Merck), methyl red (Merck), metanol(Merck), indikator pp, $\mathrm{NaOH}$ p.a (Merck), $\mathrm{HCl}$ p.a (Merck), dan akuades.

Penelitian dilakukan 2 tahapan yaitu 1) menentukan pengaruh suhu air terhadap kualitas donat kentang disusun berdasarkan Rancangan Acak Kelompok (RAK) satu faktor yaitu suhu air $\left(5,13,75,22,5,31,25\right.$ dan $\left.40^{\circ} \mathrm{C}\right)$ dan diulang 3 kali. Tahap 2) menentukan suhu air yang optimal untuk mendapatkan volume pengembangan donat yang maksimal dilakukan menggunakan Response Surface Methodology (RSM) One Factor model kuadratik dengan variabel bebas suhu air $\left(\mathrm{X}_{1}\right)(5 ; 13,75 ; 22,5$; 31,$25 ; 40$; 5 ; dan $40^{\circ} \mathrm{C}$ ) dan variabel respon volume pengembangan $\left(\mathrm{Y}_{1}\right)$. Suhu air optimal (menghasilkan donat dengan volume pengembangan maksimal) dianggap sebagai perlakuan terbaik. Donat dari perlakuan terbaik selanjutnya dianalisis sifat kimia dan dihitung informasi nilai gizinya.

\section{Pembuatan Donat Mengandung Kentang (Bahalwan, 2016 dengan modifikasi)}

Kentang segar dicuci bersih, dibelah menjadi 2 bagian, dikukus pada air mendidih selama 30 menit hingga kentang matang. Selanjutnya kentang dikupas, dihaluskan, dan didinginkan hingga suhu ruang $\left(20-25^{\circ} \mathrm{C}\right)$. Formulasi yang digunakan dalam pembuatan donat kentang dihitung berbasis berat terigu adalah kentang kukus (40\%), susu bubuk $(10 \%)$, yeast instant $(2,2 \%)$, gula halus $(20 \%)$, kuning telur $(12,8 \%)$, margarin $(15 \%)$, garam $(0,2 \%)$, dan air $(26,67 \%)$.

Bahan kering berupa terigu, gula halus dan yeast dicampur menggunakan mixer (Kitchen Aid 5KPM50, USA) kecepatan 1 selama 30 detik. Kentang kukus dan kuning telur dimasukkan ke dalam campuran lalu dicampur dengan kecepatan 2 selama 1 menit, ditambahkan air dengan suhu sesuai perlakuan, pengadukan dilanjutkan selama 2 menit dengan kecepatan 4 . Margarin dan garam ditambahkan dan pengadukan dilanjutkan selama 8 menit, kemudian kecepatan pengadukan diturunkan menjadi 2 selama 2 menit.

Adonan diistirahatkan dalam wadah tertutup kain basah selama 60 menit pada suhu $27-30^{\circ} \mathrm{C}$. Adonan selanjutnya ditimbang 30 gram, dibulatkan, dilubangi bagian tengahnya, dan difermentasi (proofing) diatas loyang bertutup kain basah selama 30 menit pada suhu $30^{\circ} \mathrm{C}$. Adonan donat selanjutnya digoreng secara deep frying pada suhu $155^{\circ} \mathrm{C}$ selama 100 detik (50 detik pada masingmasing sisi).

\section{Pengukuran Suhu Adonan Setelah Mixing, Resting dan Proofing}

Pengukuran suhu dilakukan pada adonan donat sesaat setelah terbentuk dari proses mixing, setelah proses resting dan setelah adonan selesai difermentasi (proofing). Suhu yang didapat selanjutnya diplot dalam grafik menggunakan program excel.

\section{Pengukuran Volume Spesifik}

Donat yang telah matang didinginkan 1 jam, kemudian beratnya ditimbang (g) dan volume donat $\left(\mathrm{cm}^{3}\right)$ diukur dengan metode Seed 
Displacement Method (AACCI, 2001) menggunakan biji jewawut. Volume spesifik $\left(\mathrm{cm}^{3} / \mathrm{g}\right)$ dihitung dengan membagi volume donat dengan beratnya.

Jumlah dan Luasan Pori (Datta et al., 2007)

Sampel dipotong vertikal dengan ketebalan $2 \mathrm{~cm}$. kemudian potongan sampel di scan menggunakan scanner (Canon CanoScan LiDE 110, Vietnam), lalu di crop sehingga menghasilkan ukuran 200x200 pixel $(5,3 \times 5,3$ $\mathrm{cm})$, selanjutnya gambar dianalisa dengan software ImageJ. Format gambar diubah menjadi Black and White. Skala diatur, dimana distance in pixel diisi 11,5; known distance diisi 1,00; dan unit of length diisi mm. Pilih Analyze Particle, akan muncul hasil jumlah pori (total counts) dan luasan (area).

\section{Tekstur Profil}

Donat yang telah digoreng, didinginkan 1 jam, kemudian diukur menggunakan alat CT3 Texture Analyzer (Brookfield Engineering Labs Inc., USA) dengan software CT V1.4 Build 17. Hasil analisa meliputi hardness, cohesiveness, dan springiness.

\section{Daya Serap Minyak (Yuwono dan Susanto, 1998)}

Berat pan penggoreng beserta minyak ditimbang (A). Minyak dipanaskan, lalu bahan dimasukkan dan digoreng dalam kondisi dan waktu yang ditentukan. Bahan diambil dan ditiriskan. Berat pan dan minyak di dalamnya ditimbang (B)

$$
\begin{aligned}
& \% \text { daya serap }=\frac{(\mathrm{A}-\mathrm{B})(\mathrm{g})}{\text { beratsampel awal }(\mathrm{g})} \times 100 \% \ldots . . .(1) \\
& \text { Pengujian Kimia } \\
& \text { Donat kentang yang enghasilkan }
\end{aligned}
$$

volume pengembangan maksimal selanjutnya dilakukan analisa kimia meliputi kadar air metode oven (AOAC, 1990); kadar lemak metode soxhlet (AOAC 1990); kadar protein metode Kjeldahl (AOAC, 1990); kadar serat kasar (AOAC, 1990); kadar abu (AOAC, 1990); kadar total gula (AOAC, 1990); kadar karbohidrat (by difference); dan informasi nilai gizi (berdasar kebutuhan energi $2150 \mathrm{kkal}$ ).

\section{Analisis Data}

Pengaruh suhu air terhadap kualitas donat diuji dengan ANOVA menggunakan software Minitab 17. Data dengan hasil beda nyata $(\alpha=0,05)$ dilanjutkan dengan uji $B N T$ (Beda Nyata Terkecil) 5\%. Penentuan suhu air optimal menggunakan metode Response Surface Methode (RSM) single factor yaitu suhu air (XI) dengan respon (YI) volume pengembangan donat. Data dianalisis menggunakan aplikasi Design Expert 10.0.0.

\section{HASIL DAN PEMBAHASAN}

\section{Suhu Terigu dan Adonan pada Berbagai Tahapan Pembuatan Donat}

Gambar 1. menunjukkan bahwa suhu air yang ditambahkan menentukan suhu adonan setelah mixing dan resting, namun demikian setelah proses proofing yang dilakukan dengan cara difermentasikan dalam suhu ruang, maka suhu adonan hampir sama mendekati suhu ruang. Suhu terigu yang digunakan adalah 26 ${ }^{\circ} \mathrm{C}$, dan karena terjadi gesekan mekanis selama mixing, suhu adonan donat meningkat menjadi 29-33 ${ }^{\circ} \mathrm{C}$. Menurut The Artisan Baker (2016) suhu adonan setelah mixing ditentukan oleh suhu tepung, suhu air, suhu ruang dan gesekan selama proses mixing. Pada penelitian ini, suhu terigu yang digunakan sama yaitu $26^{\circ} \mathrm{C}$, suhu ruang sama $\left(25-26^{\circ} \mathrm{C}\right)$, dan proses mixing menggunakan alat (standing mixer) dan durasi sama, sehingga perbedaan suhu adonan setelah mixing ditentukan utamanya oleh suhu air yang ditambahkan.

Suhu adonan setelah resting sedikit turun menjadi antara $28-31^{\circ} \mathrm{C}$. Menurut The Artisan Baker (2016) suhu ideal adonan dalam proses fermentasi adalah $20-25^{\circ} \mathrm{C}$, suhu di bawah $20^{\circ} \mathrm{C}$ menyebabkan aktivitas yeast rendah sedangkan di atas suhu $30^{\circ} \mathrm{C}$ aktivitas yeast terlalu cepat. Suhu adonan donat setelah proofing berkisar $25-26^{\circ} \mathrm{C}$. Tujuan proofing umumnya adalah membiarkan adonan hingga mencapai volume optimalnya. Suhu adonan dalam proofing umumnya $22-29^{\circ} \mathrm{C}$, suhu adonan yang terlalu dingin dapat menyebabkan volume pengembangan minim dan struktur crumb padat (The Artisan Baker, 2016).

\section{Pengaruh Suhu Air terhadap Karakter Fisik Donat}

\section{Volume Spesifik}

Volume spesifik pada donat kentang berkisar antara $2,62 \mathrm{~cm}^{3} / \mathrm{g}$ hingga $4,76 \mathrm{~cm}^{3} / \mathrm{g}$ dan secara statistik dipengaruhi secara nyata oleh 
suhu air yang digunakan. Volume spesifik donat meningkat dengan peningkatan suhu air dari $5^{\circ} \mathrm{C}$ dan mencapai maksimal pada suhu $22,5^{\circ} \mathrm{C}$, peningkatan suhu air lebih lanjut menurunkan volume spesifik donat (Tabel 1). Visualisasi donat yang dibuat dengan berbagai suhu air dapat dilihat pada Gambar 2.

Jika dikaitkan dengan data suhu adonan (Gambar 1) yang dihasilkan dari suhu air yang berbeda, terlihat bahwa air dengan suhu yang lebih rendah akan menghasilkan suhu adonan yang lebih rendah pula, terutama sampai pada tahapan akhir resting. Meningkatnya volume spesifik donat dengan kenaikan suhu air sampai $22,5^{\circ} \mathrm{C}$ dapat disebabkan oleh peningkatan aktivitas yeast dalam menghasilkan gas $\mathrm{CO}_{2}$ yang akan menyebabkan kenaikan percepatan pertumbuhan gelembung gas yang dihasilkan dalam proses mixing (pencampuran).

Menurut Chiotellis and Champbell (2003) gas yang dihasilkan oleh yeast akan larut dalam cairan adonan dan kemudian mengalir ke dalam gelembung udara yang terbentuk saat pengadukan adonan (mixing). Peningkatan suhu fermentasi akan meningkatkan kecepatan perbesaran gelembung gas pada adonan karena kenaikan produksi $\mathrm{CO}_{2}$ oleh yeast dan karena pendeknya waktu transit $\mathrm{CO}_{2}$ di dalam cairan adonan.
Pada suhu air yang lebih tinggi (diatas 22,5 sampai $40^{\circ} \mathrm{C}$ ), menyebabkan suhu adonan juga lebih tinggi. Peningkatan suhu lebih lanjut dapat menyebabkan produksi $\mathrm{CO}_{2}$ berlebihan dan pada durasi fermentasi yang sama menyebabkan adonan mengembang lebih besar namun mudah turun (collapse) saat disentuh untuk digoreng karena keterbatasan jaringan gluten untuk menahan gas, sehingga hal ini menurunkan nilai volume spesifiknya. Sangat penting membedakan antara produksi gas dan retensi gas dalam fermentasi adonan. Produksi gas ditentukan oleh kinerja yeast dan retensi gas bergantung pada karakteristik matriks gluten. Volume adonan yang diinginkan pada produk yang difermentasi oleh yeast akan terjadi ketika adonan menyediakan lingkungan yang diinginkan untuk pertumbuhan yeast serta di waktu yang sama, memiliki matriks gluten yang mampu menahan gas secara maksimum (Sahlstrøm, et al., 2004).

\section{Daya Serap Minyak}

Daya serap minyak oleh donat berkisar antara $8,37-11,67 \%$, dan secara statistik suhu air berpengaruh nyata terhadap daya serap minyak. Nilai daya serap minyak tertinggi terdapat pada donat dengan suhu air $40^{\circ} \mathrm{C}$, sedangkan nilai daya serap minyak terendah terdapat pada donat dengan suhu air $22,5{ }^{\circ} \mathrm{C}$ (Tabel 1).

Tabel 1. Pengaruh suhu air terhadap volume spesifik, daya serap minyak, jumlah dan luasan pori donat

\begin{tabular}{lllll}
\hline $\begin{array}{l}\text { Suhu } \\
\left({ }^{\circ} \mathbf{C}\right)\end{array}$ & $\begin{array}{l}\text { Volume Spesifik } \\
\left(\mathbf{c m}^{3} / \mathbf{g}\right)\end{array}$ & $\begin{array}{c}\text { Daya Serap } \\
\text { Minyak }(\%)\end{array}$ & Jumlah Pori & Luasan Pori $\left(\mathbf{m m}^{2}\right)$ \\
\hline 5 & $2,75 \pm 0,05 \mathrm{c}$ & $10,93 \pm 0,04 \mathrm{~b}$ & $257 \pm 10 \mathrm{bc}$ & $0,22 \pm 0,08$ \\
13,75 & $4,14 \pm 0,14 \mathrm{ab}$ & $9,65 \pm 0,07 \mathrm{c}$ & $304 \pm 64 \mathrm{~b}$ & $0,21 \pm 0,03$ \\
22,5 & $4,40 \pm 0,71 \mathrm{a}$ & $8,37 \pm 0,38 \mathrm{~d}$ & $487 \pm 67 \mathrm{a}$ & $0,12 \pm 0,02$ \\
31,25 & $4,31 \pm 0,20 \mathrm{a}$ & $9,07 \pm 0,04 \mathrm{~cd}$ & $300 \pm 9 \mathrm{~b}$ & $0,15 \pm 0,04$ \\
40 & $3,74 \pm 0,01 \mathrm{~b}$ & $11,67 \pm 0,01 \mathrm{a}$ & $217 \pm 3 \mathrm{c}$ & $0,21 \pm 0,05$ \\
\hline
\end{tabular}

Keterangan:

1. Setiap data merupakan rerata dari 3 kali ulangan

2. Angka di belakang simbol \pm merupakan standar deviasi

3. Angka yang didampingi notasi berbeda menunjukkan perbedaan nyata $(\alpha=0,05)$ 


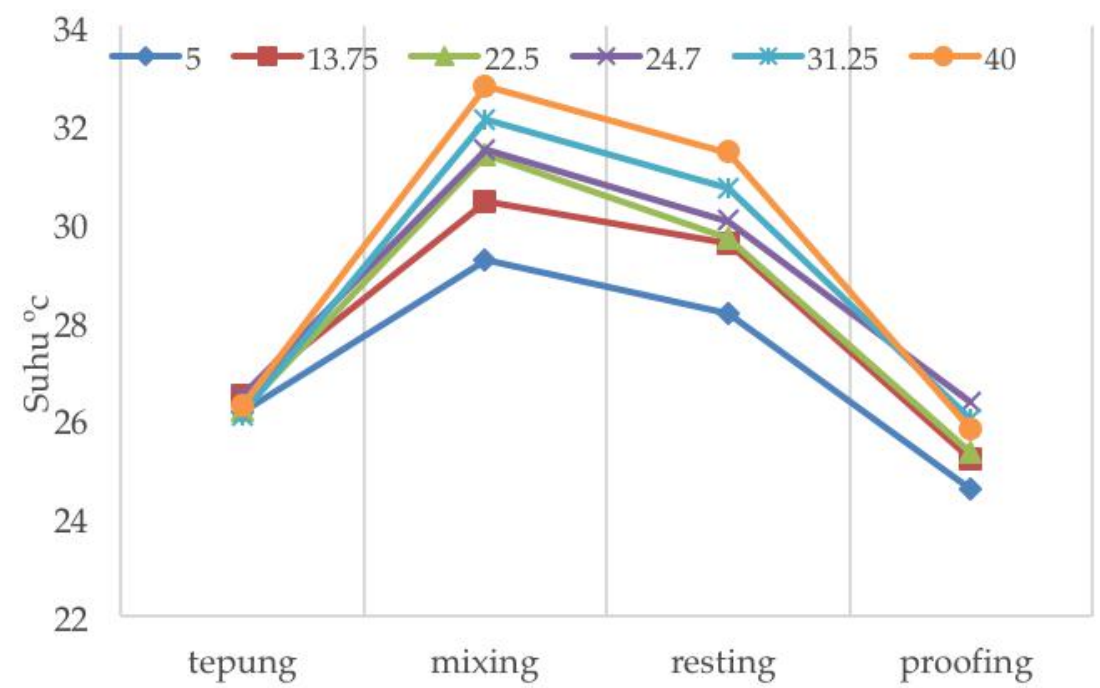

Gambar 1. Suhu terigu dan adonan donat sesaat setelah mixing, resting dan proofing

Proses penggorengan menyebabkan air menguap, menyebabkan crust kering dan tebal, sehingga tekstur kulit terluar (crust) donat menjadi crispy/crunchy, tetapi bagian dalam (crumb) lembut. Struktur crust yang porous menyebabkan minyak bisa masuk ke dalam bahan selama dan setelah penggorengan, yang menyebabkan kenaikan kadar lemak produk yang dihasilkan (Mellema, 2003). Kenaikan daya serap minyak pada donat yang dibuat dengan air bersuhu $31,25-40^{\circ} \mathrm{C}$ dapat disebabkan selain karena adanya kehilangan air dalam bahan, juga karena struktur pori dari kedua donat mengandung kentang tersebut lebih besar sehingga mampu menyerap minyak lebih banyak.

Penelitian Lee et al. (2017) menunjukkan bahwa donat dengan struktur rongga yang lebih padat yang diakibatkan oleh pembentukan matrik dalam adonan oleh tepung beras mikropartikel dan kulit kedelai memiliki daya serap minyak $30 \%$ lebih rendah dari donat biasa.

\section{Jumlah dan Luasan Pori}

Jumlah pori pada donat kentang berkisar antara 188 hingga 549 , sedangkan luasan pori berkisar antara 0,094 hingga 0,333 $\mathrm{mm}^{2}$. Visualisasi pori donat yang dibuat dengan berbagai suhu air dapat dilihat pada Gambar 2. Uji statistik menunjukkan bahwa suhu air yang ditambahkan berpengaruh nyata terha- dap jumlah pori tetapi tidak berpengaruh nyata terhadap luasan pori donat (Tabel 1).

Donat yang dibuat dengan suhu air $22,5^{\circ} \mathrm{C}$ memiliki jumlah pori terbanyak dengan luasan pori yang terkecil. Hal ini dapat dikaitkan dengan kinerja yeast. Yeast akan tumbuh dan menghasilkan $\mathrm{CO}_{2}$ dengan baik pada suhu $22,5^{\circ} \mathrm{C}$, peningkatan suhu dapat mempercepat metabolisme yeast dan meng-hasilkan $\mathrm{CO}_{2}$ yang lebih banyak, sehingga pori menjadi lebih besar. Hasil yang sama dila-porkan oleh Basaran (2003) bahwa roti yang dipersiapkan dengan mengaduk adonan pada suhu $23^{\circ} \mathrm{C}$ memiliki struktur sel yang lebih bagus jika dibandingkan dengan roti yang adonannya diaduk pada suhu $17^{\circ} \mathrm{C}$ dan $30^{\circ} \mathrm{C}$.

Karbon dioksida yang dihasilkan saat proses fermentasi larut dalam fase air (aqueous) pada adonan, kemudian bermigrasi menuju nuklei gelembung udara yang terbentuk saat pencampuran (mixing). Pertumbuhan pori gas dalam adonan bergantung pada ukuran pori dan komposisi adonan itu sendiri. Beberapa bahan berpengaruh dalam stabilitas adonan serta menghambat peleburan atau penggabungan antara gas satu dengan gas lain (coalescence) (Ali, et al., 2012). Akan tetapi untuk bisa menghasilkan produk roti dengan struktur remah (crumb grain) yang selalu seragam cukup sulit dicapai (Angioloni et al. 2009) 


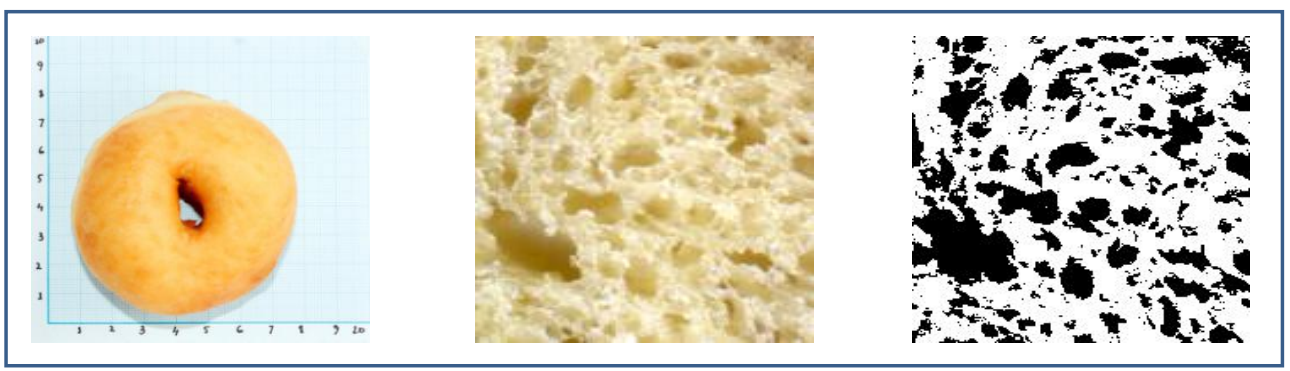

(a)

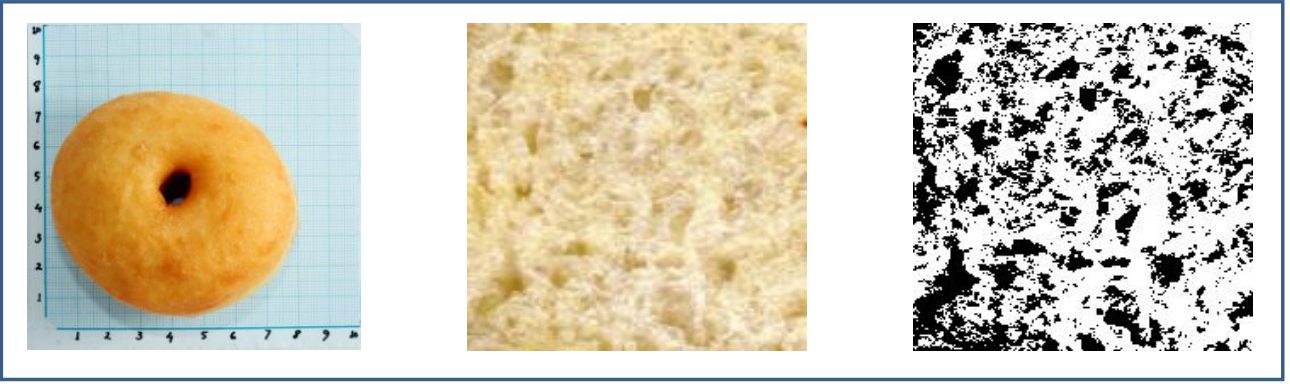

(b)

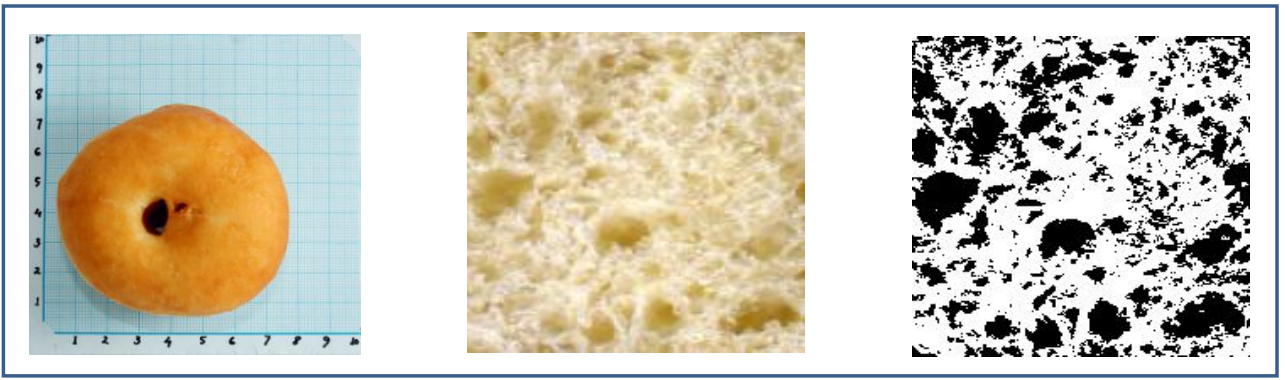

(c)

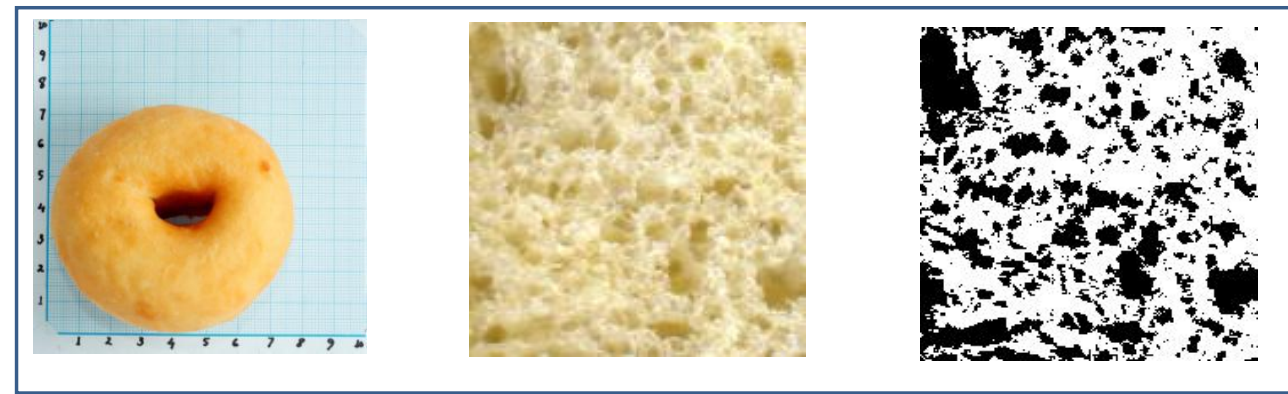

(d)

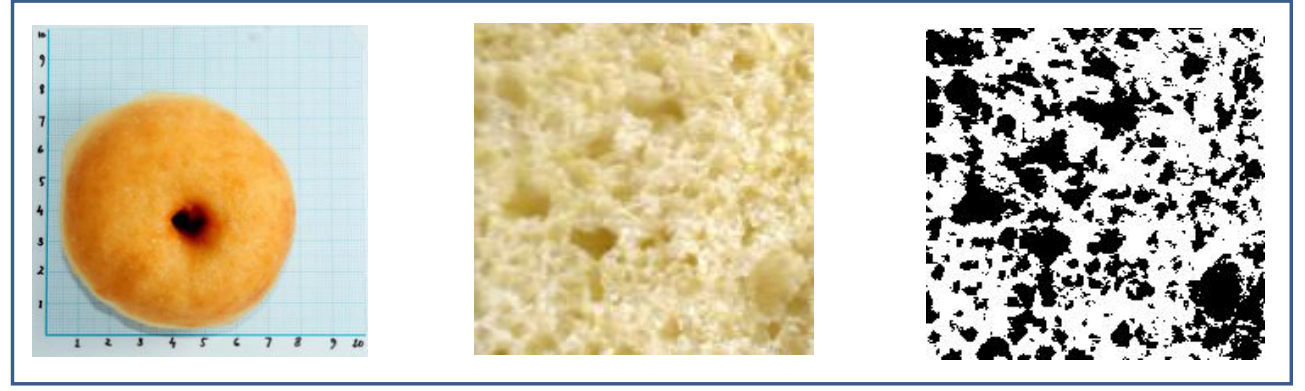

(e)

Gambar 2. Volume donat mengandung kentang dan irisan pori pada suhu air (a) $5^{\circ} \mathrm{C}$; (b) $13,75^{\circ} \mathrm{C}$; (c) $22,5^{\circ} \mathrm{C}$; (d) $31,25^{\circ} \mathrm{C}$; dan (e) $40^{\circ} \mathrm{C}$ 
Tabel 2. Pengaruh suhu air terhadap hardness, cohesiveness dan springiness donat

\begin{tabular}{lccc}
\hline \multicolumn{1}{c}{ Suhu $\left({ }^{\circ} \mathbf{C}\right)$} & Hardness $(\mathbf{N})$ & Cohesiveness & Springiness $(\mathbf{m m})$ \\
\hline 5 & $147,60 \pm 28,92$ & $0,76 \pm 0,04$ & $4,18 \pm 0,29$ \\
13,75 & $148,25 \pm 12,23$ & $0,73 \pm 0,13$ & $4,15 \pm 0,35$ \\
22,5 & $142,90 \pm 54,45$ & $0,82 \pm 0,01$ & $4,41 \pm 0,25$ \\
31,25 & $92,80 \pm 29,27$ & $0,85 \pm 0,03$ & $4,60 \pm 0,18$ \\
40 & $174,00 \pm 45,40$ & $0,81 \pm 0,02$ & $4,20 \pm 0,21$ \\
\hline
\end{tabular}

Keterangan:

1. Data hardness, cohesiveness, dan springiness merupakan rerata dari 2 kali ulangan

2. Data kekerasan merupakan rerata dari 3 kali ulangan

3. Angka di belakang simbol \pm merupakan standar deviasi

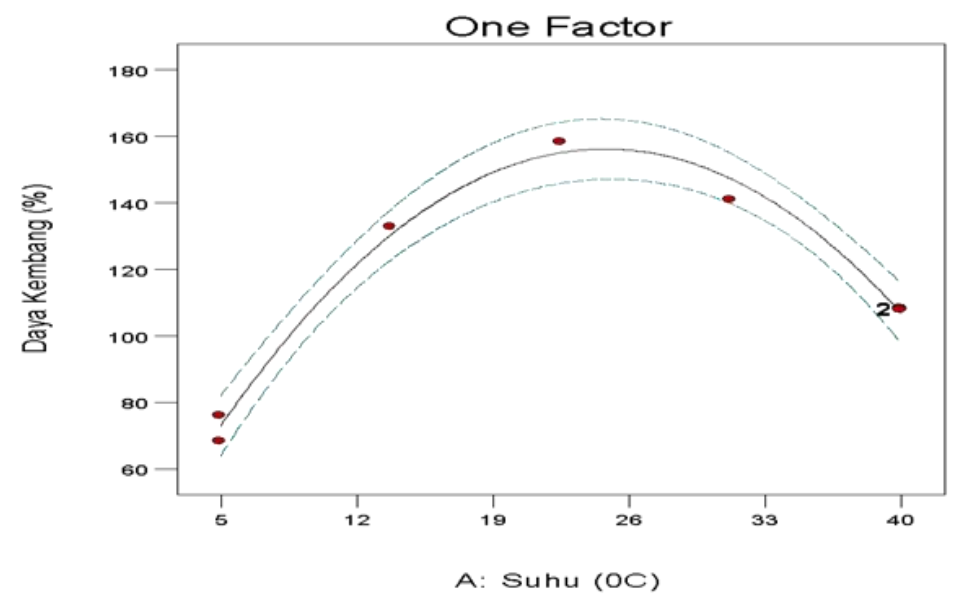

Gambar 3. Kurva optimasi pengaruh suhu air terhadap volume pengembangan donat kentang. Puncak garis melengkung merupakan titik optimum suhu air.

\section{Tekstur}

Tekstur (hardness, cohesiveness, maupun springiness) pada donat mengandung kentang yang diukur satu jam setelah proses penggorengan tidak dipengaruhi secara nyata oleh suhu air yang digunakan dalam formulasi (Tabel 2). Hal ini menunjukkan bahwa donat kentang memiliki profil tekstur yang sama pada satu jam pertama setelah penggorengan dan belum terjadi staling, namun bisa jadi akan berubah dengan peningkatan umur simpan donat. Lee et al. (2012) menyatakan bahwa amilosa dan amilopektin mengalami retrogradasi selama penyimpanan roti. Seperti halnya dengan donat, setelah digoreng dan didinginkan beberapa saat, maka retrogradasi dalam pati donat dapat terjadi yang berakibat pada mengerasnya tekstur.

Cohesiveness merupakan karakteristik yang berhubungan saat produk dikunyah dalam mulut. Nilai hardness semakin menurun, maka nilai cohesiveness dan springiness akan semakin naik, begitu pula sebaliknya (Tsai, et al., 2014). Sedangkan springiness digunakan untuk menyatakan elastisitas crumb donat, dan juga merupakan parameter penting untuk menentukan derajat staling pada roti (Tian et al. 2009). Sehingga, jika suatu produk donat memiliki nilai hardness yang rendah, maka nilai cohesiveness dan springiness yang diperoleh akan tinggi, begitu pula sebaliknya.

Optimasi Suhu Air yang Ditambahkan terhadap Volume Pengembangan Donat Kentang

Grafik hubungan antara suhu air dan volume pengembangan donat tersaji dalam Gambar 3. Volume pengembangan donat yang dibuat dengan penambahan air dengan suhu mulai dari 5 sampai $40^{\circ} \mathrm{C}$ menunjukkan pola bell shape, meningkat dari suhu air $5^{\circ} \mathrm{C}$ mencapai optimum pada suhu air $22,5^{\circ} \mathrm{C}$ dan kemudian menurun lagi saat suhu air ditingkatkan sampai $40^{\circ} \mathrm{C}$. Hal ini dapat dikaitkan 
dengan aktivitas yeast yang berperan untuk menghasilkan gas $\mathrm{CO}_{2}$. Yeast dapat tumbuh baik pada suhu sekitar $25-30^{\circ} \mathrm{C}$.

Suhu adonan yang rendah, menyebabkan kerja yeast akan lambat sehingga dibutuhkan waktu yang lebih lama saat fermentasi agar menghasilkan volume dengan pengembangan tinggi (The Artisan Baker, 2016). Pada range suhu $20-40^{\circ} \mathrm{C}$, tingkat fermentasi yeast akan meningkat dua kali lipat setiap kenaikan suhu sebesar $10^{\circ} \mathrm{C}$ (Khatkar, 2005). Hal ini dapat menyebabkan produksi $\mathrm{CO}_{2}$ yang berlebihan melebihi kapasitas jaringan adonan donat untuk menahan $\mathrm{CO}_{2}$, sehingga banyak $\mathrm{CO}_{2}$ yang terlepas ke udara dan volume pengembangan donat menurun.

\section{Verifikasi Hasil Optimum}

Verifikasi dilakukan dengan tujuan untuk membuktikan bahwa solusi titik optimum yang diberikan software Design Expert 10 adalah nyata sesuai dengan penelitian sebenarnya. Verifikasi dilakukan dengan mencari rentang dari suhu level terendah hingga tertinggi untuk menghasilkan tingkat volume pengembangan yang paling maksimum. Berdasarkan hasil verifikasi dari Design Expert 10, suhu optimal air untuk menghasilkan volume pengembangan donat kentang yang maksimal adalah $24,7^{\circ} \mathrm{C}$.

Hasil prediksi dari solusi titik optimum respon volume pengembangan sebesar $156,126 \%$, sedangkan hasil verifikasi yang didapat dengan penelitian sesungguhnya sebesar $155,937 \%$. Perbedaan nilai respon volume pengembangan hasil verifikasi dengan nilai prediksi adalah sebesar $0,121 \%$. Hasil perbandingan tersebut lebih kecil dari 5\% yang berarti nilai verifikasi telah sesuai dengan nilai prediksi. Selanjutnya, donat dengan penambahan air dengan suhu $24,7^{\circ} \mathrm{C}$ dianggap sebagai donat perlakuan terbaik, yang dikarakterisasi kimia dan informasi nilai gizinya.

\section{Karakteristik Kimia dan Informasi Nilai Gizi Donat Kentang Perlakuan Terbaik}

Kadar air donat kentang adalah 28,31\%, sedikit lebih tinggi dari kadar air donat komersial (yang terbuat dari tepung terigu) sebesar $28,01 \%$. Kentang yang ditambahkan dalam pembuatan donat adalah kentang kukus yang halus, sehingga memiliki kadar air yang tinggi (79,53\%). Selanjutnya serat kentang disebutkan oleh Ramaswamy et al., (2013) memiliki water holding capacity yang baik karena didalamnya terdapat pektin jenis rhamnogalakturonan tipe I dan II.

Kadar abu donat kentang adalah 0,69\%, lebih rendah jika dibandingkan dengan donat komersial 1,08\%. Hal ini dapat terjadi karena rendah tingginya kandungan mineral di dalam bahan-bahan pembuatan donat atau penambahan bahan lain yang akan menambah nilai kadar abu dalam produk. Rendahnya nilai abu dapat disebabkan karena penyumbang terbesar nilai abu pada donat adalah garam dengan rumus molekul $\mathrm{Na}$ dan $\mathrm{Cl}$, serta kandungan mineral dari air yang ditambahkan, serta tidak adanya penambahan leavening agent seperti baking powder atau baking soda dan penggunaan hard-water.

Kadar protein donat kentang berada pada angka $8,42 \%$ lebih tinggi jika dibandingkan dengan donat komersial. Perbedaan formulasi diduga sebagai penyebabnya, donat kentang melibatkan penambahan kuning telur $(12,8 \%)$ dan susu bubuk (10\%) yang cukup banyak. Kuning telur dan susu bubuk adalah sumber protein masing-masing mengandung 15,865 (USDA, 2018) dan 23\%.

Donat kentang memiliki kadar lemak sebesar $17,48 \%$, lebih rendah jika dibandingkan dengan donat komersial $21,82 \%$. Perbedaan ini dapat disebabkan oleh jumlah shortening seperti margarin atau mentega, kuning telur, serta banyaknya minyak yang terserap ke dalam produk saat penggorengan. Adanya penambahan bahan pengisi seperti kentang yang telah digelatinisasi terlebih dahulu dengan cara dikukus mampu menurunkan kadar lemak serta penyerapan minyak ke dalam produk. Hal ini sesuai dengan Shih et al. (2001), bahwa tepung beras yang telah digelatinisasi kemudian ditambahkan pada bahan adonan mampu menurunkan kadar lemak donat. Velez-Ruiz et al. (2003) juga menambahkan bahwa penggorengan menyebabkan struktur adonan menjadi lebih kompak (terbentuk crust) sehingga ketika poin tersebut tercapai maka penyerapan minyak tidak akan lagi berlanjut ke dalam crumb.

Kadar total gula pada donat mengandung kentang suhu $24,7^{\circ} \mathrm{C}$ sebesar $14,55 \%$, lebih rendah dibandingkan dengan donat komersial $16,36 \%$. Total gula dipengaruhi oleh banyaknya gula yang ditambahkan serta jenis bahan pengembang yang digunakan. Jika donat menggunakan bahan pengembang yeast maka akan terjadi proses fermentasi, namun jika donat menggunakan bahan pengembang 
kimia seperti karbonat, tidak diperlukan proses fermentasi. Proses fermentasi pada produk donat melibatkan gula sebagai makanan pertama ragi yeast yang kemudian diubah menjadi etanol dan karbon dioksida yang membuat adonan menjadi mengembang. Kadar gula yang rendah dapat terjadi karena fermentasi dari yeast berjalan optimal pada suhu tersebut sehingga sebagian besar gula telah dipecah menjadi etanol dan karbon dioksida. Menurut Khatkar (2005), saat proses fermentasi terjadi konversi pati menjadi maltosa dan dekstrin oleh enzim diastase, selanjutnya maltosa diubah oleh maltase menjadi dekstrosa, dan dekstrosa diubah menjadi karbondioksida dan alkohol oleh enzim zimase. Adanya penambahan topping juga mempengaruhi kadar total gula dari donat itu sendiri.

Kadar serat kasar dari produk donat mengandung kentang suhu $24,7{ }^{\circ} \mathrm{C}$ sebesar $5,41 \%$. Tingginya kadar serat kasar dapat terjadi akibat adanya penambahan kentang kukus. Kentang kukus mengandung serat yang cukup tinggi serta adanya pati resisten yang terkandung di dalamnya juga dapat terhitung sebagai serat. karena pati resisten merupakan jenis pati yang tidak dapat larut dalam asam maupun basa. Sari dkk. (2013) menyatakan bahwa lebih dari $12,5 \%$ pati kentang merupakan resistant starch tipe 2 (RS2). Pati resisten tidak dapat dicerna dan diserap dalam usus halus individu yang sehat, dan bersifat resisten terhadap hidrolisis enzim amilase. Penambahan kentang kukus yang tinggi serat mampu menurunkan tingkat staling pada produk bakery.

Informasi nilai gizi donat didapatkan dengan perhitungan data yang diperoleh dari hasil analisa kimia. Perhitungan \%AKG berdasarkan kebutuhan energi sebesar 2150 kkal, hal ini sesuai dengan Peraturan Kepala Badan Pengawas Obat dan Makanan Republik Indonesia Nomor 9 Tahun 2016 tentang Acuan Label Gizi Pangan Olahan untuk Umum. Setiap takaran saji donat kentang (65 gram) mampu memenuhi kebutuhan protein sebesar 9\%, karbohidrat sebesar 9\%, lemak sebesar $18 \%$ dengan total kalori sebesar $240 \mathrm{kkal}$ (100 kkal merupakan energi dari lemak).

\section{SIMPULAN}

Donat mengandung kentang dengan berbagai perlakuan suhu air yang ditambahkan memberikan pengaruh nyata terhadap volume spesifik, daya serap minyak dan jum-lah pori. Peningkatan suhu air dari 5 ke $22,5^{\circ} \mathrm{C}$ dapat meningkatkan volume spesifik dan jumlah pori, serta menurunkan daya serap minyak donat kentang, namun tren berkebalikan terjadi pada suhu air yang lebih tinggi. Perlakuan suhu air tidak memberikan pengaruh nyata terhadap tekstur seperti hardness, cohesiveness, dan springiness, serta luasan pori. Hasil optimasi Response Surface Methodology (RSM) One Factor model kuadratik memberi-kan pengaruh nyata pada suhu air yang ditambahkan terhadap volume spesifik dan suhu $24,7^{\circ} \mathrm{C}$ merupakan suhu air optimum yang dapat menghasilkan donat dengan volume spesifik (pengembangan) maksimal.

\section{DAFTAR PUSTAKA}

AACC International. 2001. Approved Method of Analysis, 11th Ed. Method 10-05.01. Guidelaines for Measurement of Volume by Rapeseed Displacement. Approved October 17, 2001. AACC International, St Paul, MN, USA. http:// methods.aaccnet. org/summaries/10-05-01.aspx

Ali, A., Shehzad. A., Khan, M.R., Shabbir, M.A., Amjid M.R. 2012. Yeast, its types and role in fermentation during bread making process-A Review. Pakistan Journal of Food Sciences. 22 (3), 171-179. https:// www.researchgate.net/publicati on/328052441_Yeast_its_types_and_role_ in_fermentation_during_bread_making_ process-_A_review

Angioloni, A., Collar C. 2009. Bread crumb quality assessment: a plural physical approach. European Food Research and Technology. 229, 21-30. https:// doi.org/10 .1007/s00217-009-1022-3

AOAC. 1990. Official Methods of The Analysis of Association of Analytical Chemists International. 15th Ed. Association of Official Analytical Chemists, Arlington, Virginia. https://law.resource.org/pub/ us/cfr/ibr/002/aoac.methods.1.1990.pdf

Bahalwan. F. 2016. Resep Donat Kentang. http://ncc-indonesia.com diakses pada tanggal 13 Agustus 2016 pukul 17.48 WIB.

Chiotellis E and Campbell GM. 2003. Proving of bread dough I modelling the evaluation of the bubble size distribution. 
Food and Bioproducts Processing. 81, 194206. https://doi.org/10.1205/0960308033 22437965

Datta, A., K., Sahan, S., Sumnu, G., Keskin, S.O. 2007. Porous media charac-terization of breads baked using novel heating modes. Journal of Food Engineering. 79, 106-116. https://doi.org/10.1016/j.jfoodeng.2006. 01.046

Elmehdi, H.M., Page, J.H., and Scanlon, M.G. 2007. Evaluating dough density changes during fermentation by different techniques. Cereal Chemistry 84(3), 250-252. https:// doi.org/10.1094/CCHEM-84-30250

Khatkar, B.S. 2005. Bread Industry and Processes. Bakery Science and Technology. Guru Jambheswar University. Hisar Haryana. India

Lee, M.R., Lee, W.J. 2012. Wheat quality and its effect on bread staling. Journal of Agriculture and Life Science. 46(1), 153-161.

Lee, J.H., Cho A.R., Hong J.Y., Park D.J. Lim S.T. 2017. Physical properties of wheat flour composites dry-coated with microparticulated soybean hulls and rice flour and their use for low-fat doughnut preparation. Journal of Cereal Science. 56, 636643. https:// doi.org/10.1016/j.jcs. 2012.08.011

Mellema, M. 2003. Mechanism and reduction of fat uptake in deep-fat fried foods. Trends in Food Science \& Technology. 14, 364-373. https://doi.org/10.1016/S0924 -2244(03)00050-5

Murtini, E. S., Putri, D. A. (2017). Potensi edamame sebagai pengganti kuning telur dalam pembuatan donat mengandung kentang. Jurnal Teknologi dan Industri Pangan, 28(2), 102-110. https:/ / doi.org/ 10.6066/jtip.2017.28.2.102

Nouri M, Nasehi B, Samavati V, Mehdizadeh SA. 2017. Optimizing the effects of Persian gum and carrot pomace powder for development of low-fat donut with high fibre content. Bioactive Carbohydrates and Dietary Fibre. 9, 39-45

Ramaswamy, U.R., Kabel, M.A., Scols, H.A., and Gruppen, H. 2013. Structural features and water holding capacities of pressed potato fibre polysaccharides. Carbohydrate Polymers. 93, 589-596. https:// doi.org/10. 1016/j.carbpol.2012.12.057

Rosell, C.M.,5 Collar, C. 2008. Effect of various enzymes on dough rheology and bread quality. In: Porta, R., Di Pierro, P., Mariniello L, (Eds.) Recent Research Development in Food Biotechnology, Enzyme as Additive or Processing Aids. Research Signpost. 165-183.

Sahlstrøm, S., Shelton D.R. 2004. Factors influencing yeast fermentation and the effect of LMW sugars and yeast fermentation on hearth bread quality. Cereal Chemistry. 81(3), 328-335. https:// doi.org/10.1094/CCHEM.2004.81.3.328

Sari, F.K., Nurhayati, Djumarti, 2013. Ekstraksi pati resisten dari tiga varietas kentang lokal yang berpotensi sebagai kandidat prebiotik. Berkala Ilmiah Pertanian. I(2), 3842. https://jurnal.unej. ac.id/index.php/BIP/article/view/510

Shih, F.F., Daigle, K.W., Clawson E.L. 2001, Development of low oil uptake donuts. Journal of Food Science. 66 (1), 620-627. https://doi.org/10.1111/j.13652621.2001. tb15596.x

The Artisan Baker. 2016. Temperature Control Baking. http://www.theartisan.net/tem perature_control_baking_1.htm diakses pada tanggal 1 Desember 2016 pukul 00.46 WIB.

Tian Y.Q., Li, Y., Jin, Z.Y., Xu X.M., Wang J.P., Jiao, A.Q., Yu B., Talba T. 2009. $\beta$ cyclodextrin: A new approach in bread staling. Thermochimica Acta. 489, 22-26. https:/ / doi.org/10.1016/j.tca.2009.01.025

Tsai, C.L., Sugiyama, J., Shibata, M., Kokawa, M., Fujita, K., Tsuta, M., Nabetani, H., and Araki, T. 2012. Changes in the texture and viscoelastic properties of bread containing rice porridge during storage. Bioscience. Biotechnology. Biochemistry. 76(2), 331-335. https://doi.org/10.1271/ bbb. 110722

USDA. 2018. Basic Report: 01125, Egg Yolk Raw Fresh.United States Department of Agriculture. Washington DC, USA https://ndb.nal.usda.gov/ndb/foods

Velez-Ruiz, J.F, Sosa-Morales, M.E. 2003. Evaluation of physical properties of dough of donuts during deepfat frying at different temperatures. International Journal of Food Properties. 6(2), 341-353. https:// doi.org/10.1081/JFP-120017813

Wang, P., Jin, Z., Xu, X. 2015. Physicochemical alterations of wheat gluten proteins upon dough formation and frozen storage - A review from gluten. glutenin and gliadin 
perspectives. Trend in Food Science and Technology. 1-10. http://dx.doi.org/10.10 16/j.tifs.2015.10.005.

Yuwono, S., Susanto, T. 1998. Pengujian Fisik Pangan. Universitas Brawijaya. Jurusan Teknologi Hasil Pertanian. Fakultas Teknologi Pertanian. Malang.
Zhu, F. 2016. Staling of Chinese Steamed Bread: Quantification and Control. Journal Review of Trends in Food Science and Technology. 55, 118-127. https://doi.org/ 10.1016/j.tifs.2016.07.009 